\title{
Pure form of Ackermann's tumour of the tongue in a young female patient
}

\author{
Varun Patnam
}

Department of Surgical Oncology, Kasturba Medical College, Udupi, Karnataka, India

Correspondence to Dr Varun Patnam, varun.patnam@gmail.com

Accepted 24 March 2017

\section{DESCRIPTION}

A 28-year-old female presented to our outpatient department with a painless, well-circumscribed keratotic, exophytic lesion with broad base over the left lateral aspect of the tongue (figure 1). The lesion had a rough, shaggy, papillomatous surface with sharp finger-like surface projections with no surrounding induration (figure 2). She did not have any habits relevant to history. A biopsy performed at a different centre earlier to her visit here suggested of verrucous hyperplasia. Taking into consideration the history of lesion progression and the gross appearance of the lesion, a strong suspicion of verrucous carcinoma (VC) was made. A wide local excision of the lesion with $1-\mathrm{cm}$ margin was done (figure 3). The histopathology showed a verrucoid lesion lined by hyperkeratotic, acanthotic and focally inflamed stratified squamous epithelium with papillomatosis and broad and fused rete with cells showing mild anisonucleosis, overlying fibrocollagenous stroma with dense eosinophilic and lymphoplasmacytic infiltrate and congested vessels, suggestive of VC.

VC was first delineated as a clinic-pathological entity by Ackerman in $1948 .{ }^{1}$ This is a distinct variety, comprising about $2.5 \%-4 \%$ of all squamous cell carcinoma in oral cavity and is relatively uncommon. Its occurrence in tongue is rare. ${ }^{2}$ It most commonly occurs after fifth decade, in individuals with adverse habits of tobacco and alcohol. VC has excellent prognosis due to its benign indolent tumour behaviour and metastasis to regional

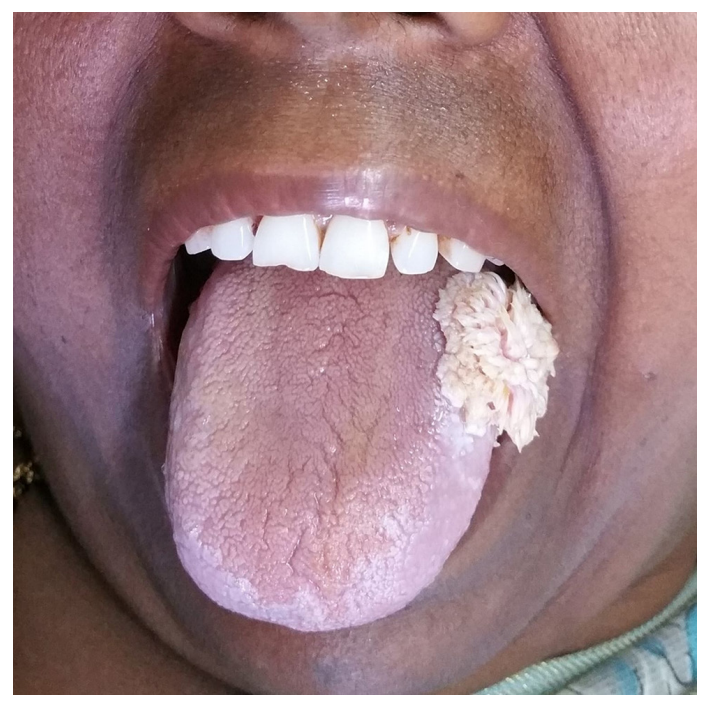

To cite: Patnam V. BMJ Case Rep Published Online First: [please include Day Month Year]. doi:10.1136/bcr-2017219784
CrossMark

Figure 1 Well-circumscribed keratotic, exophytic lesion with a broad base over the left lateral aspect of the tongue

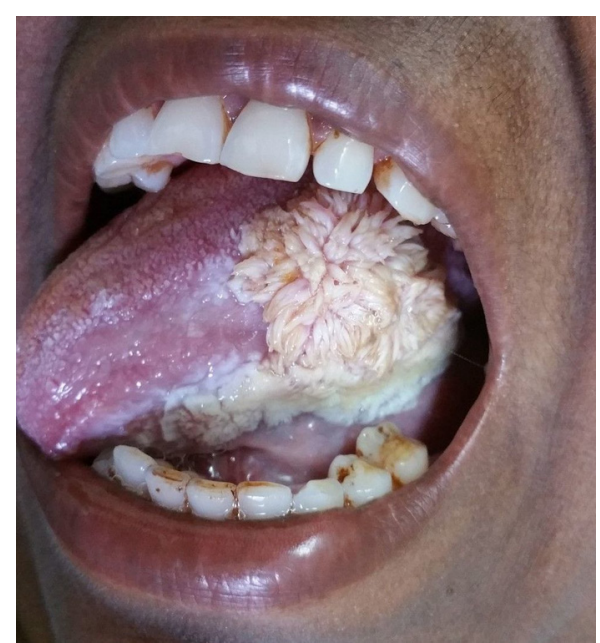

Figure 2 The lesion showing rough, shaggy, papillomatous surface with sharp finger-like surface projections with no surrounding induration.

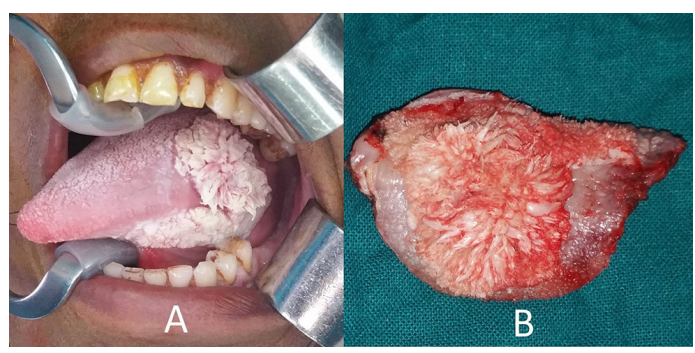

Figure 3 Intraoperative image showing the extent of the lesion (A). Post local excision specimen (B).

\section{Learning points}

- Although it has benign indolent tumour behaviour, multiple deep biopsies are recommended to distinct and distinguish from verrucous hyperplasia and other groups of squamous cell carcinoma showing verrucoid features.

- The most appropriate treatment is surgical excision. In selected patients where surgery is not possible, radiotherapy may be attempted, but some authors have reported radiationinduced anaplastic transformation.

- In patients with VC associated with leucoplakia or submucosal fibrosis, there may be 'field cancerisation' leading to multiple recurrences. Hence, a strict routine follow-up is recommended. 


\section{Images in...}

lymph nodes is very rare. $^{3}$ This lesion presenting in a young female without any habits in such a pure form has not been reported earlier. Also, the images shown in this report give the typical gross appearance of VC which may help in differential diagnosis in an unusual presentation such as this one.

Competing interests None declared.

\section{Patient consent Obtained.}

Provenance and peer review Not commissioned; externally peer reviewed.
(C) BMJ Publishing Group Ltd (unless otherwise stated in the text of the article) 2017. All rights reserved. No commercial use is permitted unless otherwise expressly granted.

\section{REFERENCES}

1 Ackerman LV. Verrucous carcinoma of the oral cavity. Surgery 1948;23:670.

2 Oliveira DT, de Moraes RV, Fiamengui Filho JF, et al. Oral verrucous carcinoma: a retrospective study in Sao Paulo Region, Brazil. Clin Oral Investig 2006;10:205-9.

3 Rekha KP, Angadi PV. Verrucous carcinoma of the oral cavity: a clinico-pathologic appraisal of 133 cases in Indians. Oral Maxillofac Surg 2010;14:211-8.

Copyright 2017 BMJ Publishing Group. All rights reserved. For permission to reuse any of this content visit http://group.bmj.com/group/rights-licensing/permissions.

BMJ Case Report Fellows may re-use this article for personal use and teaching without any further permission.

Become a Fellow of BMJ Case Reports today and you can:

- Submit as many cases as you like

- Enjoy fast sympathetic peer review and rapid publication of accepted articles

- Access all the published articles

- Re-use any of the published material for personal use and teaching without further permission

For information on Institutional Fellowships contact consortiasales@bmjgroup.com

Visit casereports.bmj.com for more articles like this and to become a Fellow 